University College, Dar es Salaam: Current Researches in pre-Colonial History (see also Africa, xl. I, Jan. I970, p. 78)

THE following projects in pre-colonial history in Tanzania are listed by the History Department, University College, Dar es Salaam, in Tanzania Zamani, no. 5, July 1969:

Dr. Israel K. Katoke (Boston University): the history of Karagwe (completed).

Mr. Peter Schmidt: multidisciplinary approach to the history of Buhaya.

Mr. Gerald W. Hartwig (Indiana University): collection of oral traditions of Ukerewe (completed).

Mr. Lorne Larson: the social, economic, and political interaction of the Roman Catholic missionaries, the colonial authorities, and the peoples of Ulanga District.

Mr. Patrick N. Redmond (School of Oriental and African Studies, London): the Ngoni of southern Tanzania.

Mrs. Beverly A. Brown (Boston University): history of Ujiji.

Mr. Walter Brown (Boston University): history of Bagamoyo.

Mr. August H. Nimtz Jr. (Indiana University): the role of tariqas in the political development of Tanzania.

Mr. Abdul M. H. Sheriff: the commercial history of Zanzibar in the late eighteenth and nineteenth centuries.

\title{
The Nembe Cultural Association
}

The Nembe Cultural Association (c/o S. D. Dambo, Secretary, Central Bank of Nigeria, Research Department, Lagos) has recently published Owoma Kalai Anumo, a booklet of traditional songs written in the Nembe (Ijaw) dialect of the Rivers State of Nigeria. The songs, generally used by children at play, are arranged in alphabetical order so that children and those wishing to study the dialect may get to know the Nembe alphabet more easily.

\section{Consortium for the Study of Nigerian Rural Development}

THe Michigan State University Consortium for the Study of Nigerian Rural Development, (Director, Glenn L. Johnson) in collaboration with the Nigerian Institute of Social and Economic Research, Ibadan, has been conducting studies in co-operation with Nigerian agencies for the past two years. The CSNRD took as its point of departure the Food and Agriculture Organization of the United Nations report Agricultural Development in Nigeria $1965-80$ and has published a series of reports on various aspects of agriculture and rural development in Nigeria. Information regarding these may be obtained from CSNRD, 204 Agricultural Hall, Michigan State University, East Lansing, Michigan 48823, U.S.A.

\section{International Institute of Differing Civilisations: The FRAG Project}

THE FRAG Project is a large-scale survey being undertaken by members of INCIDI on the obstacles and restrictions hindering agrarian reform in the developing countries. It is divided into three panels the objects of which are to discover (a) the nature, intensity, and geographical extension of the various obstacles and restrictions impeding the growth of agricultural productivity and the success of agrarian reforms in intertropical regions, (b) the steps already taken by national and other authorities to induce or encourage agrarian reform, the effects of such measures and causes of possible failure, and (c) new policies which should be promoted to ensure the success of ' genuine' agrarian reforms. The initial objective is an extensive collection of documentary material on a world scale susceptible of close comparison and recorded to facilitate its eventual computerization. A questionnaire has been sent out with the primary aim of assembling data for phase (a). Further information 